\title{
Chemical Speciation, Bioavailability and Environmental Pollution Risks of Heavy Metals in the Greenhouse Soil Amended With Sewage Sludge and Municipal Solid Waste Compost
}

\author{
Bülent Topcuoğlu
}

\begin{abstract}
A study was carried out in intensive greenhouse areas of Antalya to evaluate the effects of repeated applications of sewage sludge (SS) and municipal solid waste compost (MSWC) on the metal bioavailability, metal-bound forms and pollution effects in greenhouse soil. SS and MSWC were applied to greenhouse soil for three cultivation years and total and DTPA-extractable $\mathrm{Zn}, \mathrm{Cu}, \mathrm{Ni}, \mathrm{Pb}$ and $\mathrm{Cd}$ contents and metal speciation of greenhouse soil were determined. Additional to routine soil analysis, several environmental pollution indexes were used to evaluate the size of possible environmental pollution and risks.

SS and MSWC amendments increased both total and DTPA-extractable concentrations of $\mathrm{Zn}, \mathrm{Cu}, \mathrm{Ni}, \mathrm{Pb}$ and $\mathrm{Cd}$ in the greenhouse soil when compared with the manure application. However, the concentration of heavy metals in greenhouse soils amended with SS and MSWC were found below the referenced limits. Relative availabilities of $\mathrm{Zn}, \mathrm{Cu}$ and $\mathrm{Pb}$ in SS treatments were found greater than MSWC treatments. Compared to manure application, SS and MSWC treated soil often show significantly increased heavy metal contents, especially $\mathrm{Zn}, \mathrm{Cu}, \mathrm{Pb}, \mathrm{Ni}$ and $\mathrm{Cd}$. Repeated applications of SS and MSWC amendments were significantly increased bioavailable metals in the greenhouse soil compared to the manure. In sewage sludge and MSWC treatments, 'total' concentrations of all metals were found below the pollutant limits, but the increase in available fractions was more marked than those of total concentrations.

SS and MSWC amendments increased soluble, exchangeable and carbonate-bound fractions for all metals, especially $\mathrm{Cu}, \mathrm{Pb}$ and $\mathrm{Cd}$ studied. MSWC applications to greenhouse soil caused higher mobility values of $\mathrm{Zn}, \mathrm{Ni}, \mathrm{Pb}$ and $\mathrm{Cd}$ than SS applications. Single-factor and composite Pollution Index values of greenhouse soil amended with manure, SS and MSWC were found below the critical value. Ecological risk factors for heavy metals were found below the critical level that indicate all metals posed low risk to surrounding ecosystem in short or medium-term. However, MSWC amendments increased risk assessment code values.
\end{abstract}

Bülent Topcuoğlu , Akdeniz University Vocational School of Technical Sciences, 07058 Antalya TURKEY; btoglu@akdeniz.edu.tr
Keywords - Sewage sludge; Metals; Speciation, Bioavailability; Pollution risks.

\section{INTRODUCTION}

【 AND disposal of sewage sludge is a major environmental especially in developing countries, require municipal authorities to handle larger volumes of sewage sludge often with limited resources. The use of sewage sludge in agriculture is now a widespread disposal practice.

Sewage sludge and MSWC contain valuable plant nutrients and organic matter that can improve soil fertility. The phytonutritive capacity of compost has often been demonstrated to be analogous to that of manure; the same level of productivity, both quantitatively and qualitatively, can be maintained by replacing manure with compost $[1,2]$. However, sewage sludge and MSWC often contains potentially toxic elements, that can cause soil contamination, phytotoxicity and undesirable residues in plant and animal products [3]. As a matter of fact, pollution problems may arise if toxic metals are mobilized may then occur through consumption of such crops and intake of contaminated waters. In the long term, the use of sewage sludge and MSWC can also cause a significant accumulation of $\mathrm{Zn}, \mathrm{Cu}$, $\mathrm{Pb}, \mathrm{Ni}$ and $\mathrm{Cd}$ in the soil and plants [4].

Heavy metal pollution of agricultural soils and crops through the application of sewage sludge and MSWC as organic fertilizers is of great concern. At the present time, legislation in different countries limiting the use of sewage sludge in agriculture, refers to the total amounts of heavy metals in these wastes and in soils and recommends that soil $\mathrm{pH}$ to be maintained at 6 or higher. Nevertheless, these criteria are insufficient since mobility, environmental diffusion and bioavailability largely depend on soil physicochemical characteristics and, likewise, on trace metal chemical forms [5]. From an environmental point of view, the evaluation and forecast of food contamination is related to the bioavailable fraction of heavy metals in soil. Long-term studies are needed to improve our understanding of the effects of land application of sewage sludge on soil chemical properties. 
Today many environmental pollution risk indexes developed for water and sediments can be used for soils, organic matter and other environmental materials. Although several establishment criteria developed for soils depend on total concentrations, these criteria were frequently unsatisfied for a comprehensive environmental risk prediction. Due to potential toxicity of heavy metals to human life and environment, determining the chemical form of heavy metals in greenhouse soils is an important approach of chemical characterization and can provide useful information on its mobility and bioavailability.

The use of sewage sludge for agricultural purposes in Turkey is restricted, so far. Information on the fertilizing value of municipal solid waste composts and their effects on the heavy metal loading potentials on greenhouse soil are scarce. The aim of this study was to assess the effects of repeated applications of sewage sludge and MSWC on total and bioavailable (DTPA-extractable) contents of $\mathrm{Zn}, \mathrm{Cu}, \mathrm{Ni}$, $\mathrm{Pb}$ and $\mathrm{Cd}$ and on metal speciation and pollution risks of greenhouse soil.

\section{MATERIAL AND METHODS}

The experiment was conducted on the new constructed greenhouse representative of the major greenhouse growing area of Turkey, Antalya. The site studied is intensively cultivated and is not industrialized area. The geological materials of greenhouse area are mainly of calcareous nature and adjacent to Mediterranean sea with average $59 \mathrm{~m}$ altitude. The land is influenced by a Mediterranean climate with a high average annual rainfall $(1038,8 \mathrm{~mm} /$ year $)$, the annual average temperature being around $18,4{ }^{\circ} \mathrm{C}, 63,2 \%$ average humidity and average 148,6 sunny days per year. As for greenhouses, the annual temperature is higher inside than outside, and most of them are watered by sprinklers with ground water source at the same point. All greenhouses have passive ventilation to control temperature and humidity inside. A great number of greenhouse soils is artificially built up with a different layer of sand, organic matter and other soil source.

The analytical characteristics of the greenhouse soil are shown in Table 1 which also shows the pollutant limits of soil permitted by EU legislation [6].

The experiment entailed the use of the following organic materials for the fertilization of the greenhouse soil.

- Composted cattle manure (CM): Produced by dairy-cows in sheds with straw bedding used for control treatment.

- Sewage sludge (SS): Sewage sludge was collected from the Hurma Waste Water Treatment Plant in Antalya. Sludge sample were air-dried and sieved through a 2-mm mesh and mixed well, respectively.

- Municipal solid waste compost (MSWC): Obtained from MSW composting plant in Kemer, Antalya. Compost was produced by the composting of the organic fraction of municipal solid waste, selected mechanically at the plant.
The mean analytical characteristics of organic materials tested are given in Table 2, which also shows the of EU limits [6] for sewage sludge.

Organic materials were applied to greenhouse soil for three cultivation years as an oven-dry basis at the following rates:

- Control: 50 ton ha ${ }^{-1}$ of cattle manure,

- $\mathrm{SS}_{50}: 50$ ton $\mathrm{ha}^{-1}$ of sewage sludge,

MSWC $_{50}: 50$ ton ha ${ }^{-1}$ of municipal solid waste compost.

TABLE I: THE ANALYTICAL CHARACTERISTICS OF THE EXPERIMENTAL GREENHOUSE SOIL BEFORE TREATMENT

\begin{tabular}{l|r|r|c}
\hline Parameters & \multicolumn{2}{|c|}{ Characteristics } & $\begin{array}{c}\text { Limit values in soil, } \\
\left(\mathrm{mg} \mathrm{kg}^{-1} \text { dry wt) [6] }\right.\end{array}$ \\
\hline Texture & Loam & & \\
$\mathrm{pH}-\mathrm{H}_{2} \mathrm{O}(1: 5 \mathrm{w} / \mathrm{v})$ & 7.47 & & \\
$\mathrm{CaCO}_{3}, \%$ & 7.70 & & \\
Organic matter, \% & 2.04 & & \\
Clay,\% $<0,002 \mathrm{~mm}$ & 15,5 & & \\
$\mathrm{CEC}, \mathrm{cmol} \mathrm{kg}^{-1}$ & 9,5 & & \\
$\mathrm{EC}, \mathrm{dS} \mathrm{m}^{-1} 25^{\circ} \mathrm{C}$ & 0,8 & & \\
Total N, \% & 0.12 & & \\
$\mathrm{P}(\mathrm{ex}), \mathrm{mg} \mathrm{kg}^{-1}$ & 13.7 & & \\
$\mathrm{~K}(\mathrm{ex}), \mathrm{mg} \mathrm{kg}^{-1}$ & 96 & & \\
$\mathrm{Ca}(\mathrm{ex}), \mathrm{mg} \mathrm{kg}^{-1}$ & 1716 & & \\
$\mathrm{Mg}\left({\mathrm{ex}), \mathrm{mg} \mathrm{kg}^{-1}}^{211}\right.$ & & \\
\hline $\mathrm{Zn}, \mathrm{mg} \mathrm{kg}^{-1}$ & $88^{1}$ & $6.6^{2}$ & $150-300^{3}$ \\
$\mathrm{Cu}, \mathrm{mg} \mathrm{kg}^{-1}$ & 25 & 2.7 & $50-140$ \\
$\mathrm{Ni}, \mathrm{mg} \mathrm{kg}^{-1}$ & 16.6 & 0.48 & $30-75$ \\
$\mathrm{~Pb}, \mathrm{mg} \mathrm{kg}^{-1}$ & 45 & 4.0 & $50-300$ \\
$\mathrm{Cd}, \mathrm{mg} \mathrm{kg}^{-1}$ & 0,002 & 0,001 & $1-3$ \\
\hline
\end{tabular}

1: Total concentrations, ${ }^{2}:$ DTPA-extractable concentrations, ${ }^{3}:$ Total concentrations at soil $6<\mathrm{pH}<7$.

The control treatment (cattle manure) is representative of the normal organic matter fertilization practice adopted in the provinces of Antalya. The rates of SS and MSWC were studied in order to introduce quantities of dry organic matter analogues to those of the control. Organic materials were manually incorporated into the greenhouse soil and mixed throughout the upper $20 \mathrm{~cm}$. After the three cultivation season, greenhouse soil samples were taken at a depth of 20 $\mathrm{cm}$ and these were air-dried, sieved $(<2 \mathrm{~mm})$ and stored in polyethylene bags sealed awaiting analysis.

TABLE II: AVERAGE ANALYTICAL CHARACTERISTICS OF ORGANIC MATERIALS

\begin{tabular}{l|l|l|l|l}
\hline & $\begin{array}{l}\text { Cattle } \\
\text { Manure }\end{array}$ & SS & $\begin{array}{l}\text { MSW } \\
\text { C }\end{array}$ & $\begin{array}{l}\text { Limit } \\
\text { values [6], } \\
\text { mg kg }^{-1} \\
\text { dry wt) }\end{array}$ \\
\hline Moisture, \% & 54 & 38.6 & 35.4 & \\
$\mathrm{pH}-\mathrm{H}_{2} \mathrm{O}(1: 5 \mathrm{w} / \mathrm{v})$ & 7.96 & 6.45 & 7.66 & \\
Ash, \% & 26.2 & 44.2 & 48.5 & \\
Total N, \% & 2.12 & 1.88 & 1.15 & \\
$\mathrm{P}_{2} \mathrm{O}_{5}, \%$ & 1.77 & 2.14 & 0.77 & \\
$\mathrm{~K}_{2} \mathrm{O}, \%$ & 1.56 & 0.48 & 0.55 & \\
\hline Total $\mathrm{Zn}, \mathrm{mg} \mathrm{kg}^{-1}$ & 180 & 1660 & 1220 & $2500-4000$ \\
Total Cu, mg kg-1 & 46 & 236 & 105 & $1000-1750$ \\
Total Ni, mg kg-1 & 15 & 54 & 43 & $300-400$ \\
Total Pb, mg kg & 21 & 443 & 196 & $750-1200$ \\
Total Cd, mg kg-1 & 0,06 & 2.8 & 1.6 & $20-40$ \\
\hline
\end{tabular}


Electrical conductivity (EC) and $\mathrm{pH}$ were measured a soil:water ratio of 1:2. cation exchange capacity (CEC) was determined by $0.1 \mathrm{M} \mathrm{NN}_{4} \mathrm{AoC}$ extraction; $\mathrm{CaCO}_{3}$ content was determined by the calcimeter; organic carbon was measured by wet oxidation; and texture was determined by Bouyoucos hydrometer method. For the determination of total heavy metal concentrations, soil, SS and MSWC samples were digested in aqua regia $\left(1: 3 \mathrm{HNO}_{3} / \mathrm{HCl}\right)$ according to the international standard [7]. Bioavailable fractions of metals were extracted from soil with diethylenetriaminepentaacetic acid- $\mathrm{CaCl}_{2}$-triethanolamine adjusted to $\mathrm{pH} 7.3$ (DTPA) procedure [8].

Sequental extraction method [9] was applied to soil samples to identify metal fractions. The heavy metal sequential extraction procedure had the following steps:

- F1. $1 \mathrm{M} \mathrm{MgCl}_{2}$ (1:8 w/v, pH 7) for $1 \mathrm{~h}$ at room temperature; metals in soil solution and in exchangeable forms.

- F2. 1 M NaOAc (1:8 w/v, pH 5) for $5 \mathrm{~h}$ at room temperature; metals mainly in the carbonate fraction.

- F3. $0,04 \mathrm{M} \mathrm{NH} \mathrm{NH}_{2} \mathrm{OH} / \mathrm{HCl}$ in $25 \%(\mathrm{v} / \mathrm{v}) \mathrm{HOAc}(1: 20 \mathrm{w} / \mathrm{v})$ for $6 \mathrm{~h}$ at $96^{\circ} \mathrm{C}$; metals associated with $\mathrm{Fe}$ and $\mathrm{Mn}$ oxides.

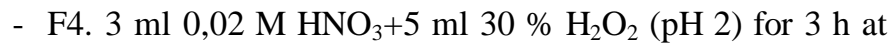
$85{ }^{\circ} \mathrm{C}$; metals associated with organic matter.

- $\mathrm{F} 5 . \mathrm{HNO}_{3}-\mathrm{HCl}$ digestion; residual fraction.

Total, bioavailable and sequential extracted metal concentrations were analysed using ICP-MS under optimised measurement conditions, and values were adjusted for oven dried $\left(12 \mathrm{~h}\right.$ at $\left.105^{\circ} \mathrm{C}\right)$ material.

Selected environmental pollution indexes for soil samples 'Mobility of Metals' (MF) [10], 'Risk assessment code' (RAC) [11], 'Single-Factor and Composite Pollution
Index of Soils' [12] and 'Potential Ecological Risk Factor Indexes' [13] were used for comprehensive and integrated evaluation of possible pollution risks of treatments.

Statistical analyses were performed by using SPSS-16 for Windows program.

\section{RESUlt AND DisCUSSION}

\section{A. Total metal contents in the soil}

Certain soil characteristics and heavy metal contents of experimental soil and their pollutant limits were given in Table 1. Experimental greenhouse soil has generally slightly alkaline reaction, moderate $\mathrm{CEC}$, low EC values and highly calcareous, and having a lower agricultural fertility without fertilization. Average total metal contents were below the limits of European Union (EU), 86/278/CEE [6] directive to agricultural soils with $\mathrm{pH}>7$. The heavy metal contents of organic materials studied (Table 2) are also well within the accepted normal range of values. A comparison of metal contents of organic materials with that of untreated soil showed that the metals $\mathrm{Zn}, \mathrm{Cu}, \mathrm{Ni}, \mathrm{Pb}$ and $\mathrm{Cd}$ were present in both SS and MSWC in greater concentrations than in the soil. The three organic materials tested differed notably in their heavy metal content. Sludge metal concentrations are considerably higher than those of MSWC and cattle manure for all metals examined. The metal concentrations in cattle manure were the lowest. The heavy metal concentrations of all organic materials are below the levels indicated by the EU (86/278/CEE) for the agricultural use of sewage sludge.

The heavy metal contents of the greenhouse soil treated with SS and MSWC are given in Table 3.

TABLE III: TOTAL AND DTPA EXTRACTABLE CONCENTRATIONS OF HEAVY METALS IN THE GREENHOUSE SOIL

\begin{tabular}{|c|c|c|c|c|c|c|c|c|c|c|c|c|c|c|c|}
\hline \multirow{2}{*}{ Treatments } & \multicolumn{3}{|c|}{$\mathrm{Zn}$} & \multicolumn{3}{|c|}{$\mathrm{Cu}$} & \multicolumn{3}{|c|}{$\mathrm{Ni}$} & \multicolumn{3}{|c|}{$\mathrm{Pb}$} & \multicolumn{3}{|c|}{$\mathrm{Cd}$} \\
\hline & Total & DTPA & $\mathrm{D} / \mathrm{T}$ & Total & DTPA & $\mathrm{D} / \mathrm{T}$ & Total & DTPA & $\mathrm{D} / \mathrm{T}$ & Total & DTPA & $\mathrm{D} / \mathrm{T}$ & Total & DTPA & $\mathrm{D} / \mathrm{T}$ \\
\hline Control & $90 \mathrm{e}$ & $7.2 \mathrm{e}$ & $8 \mathrm{e}$ & $25 \mathrm{c}$ & $2.8 \mathrm{e}$ & $11 \mathrm{c}$ & $17 \mathrm{~b}$ & 0.66 & 3.9 & $44 \mathrm{e}$ & $4 \mathrm{e}$ & $9 \mathrm{c}$ & $0.002 \mathrm{~b}$ & $<0.001$ & - \\
\hline SS & $131 \mathrm{c}$ & $43 \mathrm{c}$ & $33 \mathrm{c}$ & $30 \mathrm{~b}$ & $16 \mathrm{~b}$ & $52 \mathrm{a}$ & $17 \mathrm{~b}$ & 0.73 & 4.3 & $54 \mathrm{~b}$ & $18 \mathrm{c}$ & $33 \mathrm{~b}$ & $0.004 a$ & $<0.001$ & - \\
\hline MSWC & $102 \mathrm{~d}$ & $29 \mathrm{~d}$ & $28 \mathrm{~d}$ & $26 \mathrm{c}$ & $12 \mathrm{~d}$ & $47 \mathrm{~b}$ & $17 \mathrm{~b}$ & 0.64 & 3.8 & $47 \mathrm{~d}$ & $15 \mathrm{~d}$ & $32 \mathrm{~b}$ & $0,003 \mathrm{~b}$ & $<0.001$ & - \\
\hline Significance & $* *$ & $* *$ & $* *$ & $*$ & $* *$ & $* *$ & $*$ & NS & NS & $* *$ & $* *$ & $* *$ & $*$ & NS & NS \\
\hline
\end{tabular}

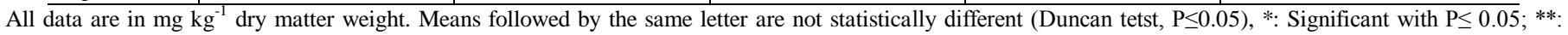
Significant with $\mathrm{P} \leq 0.01$; NS: not significant, D/T: DTPA/Total concentration rate (\%).

SS and MSWC led to a far greater introduction of the heavy metals examined and brought about a significant increase in their 'total' form in the soil when compared with the control. After SS and MSWC applications, significant changes in the total contents of $\mathrm{Zn}, \mathrm{Cu}, \mathrm{Ni}, \mathrm{Pb}$ and $\mathrm{Cd}$ among the treatments were determined. These results agree with the increase of total metal content observed in soils submitted to repeated application of metal-contaminated sewage sludge $[14,15]$.

Metals extracted from the surface $20 \mathrm{~cm}$ of soil plots, were generally increased yearly with each addition. The increases were highly significant at the $1 \%$ level for $\mathrm{Zn}, \mathrm{Cu}$ and $\mathrm{Pb}$, and $5 \%$ level for $\mathrm{Ni}$ and $\mathrm{Cd}$ (Table 3). The total $\mathrm{Zn}$, $\mathrm{Cu}$ and $\mathrm{Pb}$ contents of soil at the beginning of the experiment were 88,25 and $45 \mathrm{mg} \mathrm{kg}^{-1}$, respectively. During the trial period, at high application levels of SS, these levels were increased to 167,35 and $60 \mathrm{mg} \mathrm{kg}^{-1}$, respectively. The increase in the soil zinc content was less significant with manure than with SS and MSWC. The $\mathrm{Zn}$ and $\mathrm{Cu}$ variations were more marked with sewage sludge and consistent with the amounts of

both SS and MSWC tested. Increasing soil-metal concentrations with increasing SS and MSWC applications to soil have been reported [16]. In spite of the important increases in $\mathrm{Zn}, \mathrm{Cu}$ and $\mathrm{Pb}$ contents registered, the concentrations of metals in the soil remained below the EU legislation $(86 / 278 / \mathrm{CEE})$ for soils.

The tendency of metal accumulation in the soil in relation to amendments of SS and MSWC was in the following order: $\mathrm{Zn}>\mathrm{Pb}>\mathrm{Cu}>\mathrm{Ni}>\mathrm{Cd}$. It has been reported that increased $\mathrm{Zn}, \mathrm{Cu}$ and $\mathrm{Pb}$ levels have often been observed, both in the soil and plants, while other heavy metals-such $\mathrm{Ni}$ 
and Cd- increase less consistently [17]. Based on the cumulative research in Europe into the agronomic use of compost, heavy metals tend to accumulate in soil and plants in the following order: $\mathrm{Zn}>\mathrm{Cu}>\mathrm{Pb}>=\mathrm{Cd}>\mathrm{Ni}>\mathrm{Cr}[18]$.

\section{B. DTPA extractable metals in the soil}

In this study, bioavailability of metals was expressed in terms of concentrations extractable with DTPA. All amounts of SS and MSWC brought about significant increases in DTPA-extractable $\mathrm{Zn}, \mathrm{Cu}$ and $\mathrm{Pb}$ concentrations in comparison with the control. These results are in concordance with the data [19]. DTPA-extractable $\mathrm{Zn}, \mathrm{Cu}$ and $\mathrm{Pb}$ also registered significantly higher values in 100 ton/ha than 50 ton/ha application level of SS and MSWC (Table 3). Although the content of $\mathrm{Ni}$ in 'total' form was increased by the application of SS and MSWC, DTPA-extractable form of $\mathrm{Ni}$ was unaffected. In the all treatments, DTPA-extractable $\mathrm{Cd}$ in the soil was always below the sensitivity of analytical method (Table 3).

The maximum permissible concentrations of heavy metals in surface soils amended with sewage sludge are normally based on total concentration, although it is the bioavailable metal fraction that posses environmental concern [20]. Total concentrations of all metals were found below the pollutant limits, but the increase in DTPA-extractable fractions was more marked than those of total concentrations.

The application of SS and MSWC caused to a significant increase in the extractability of metals in the soil. The relative increase of heavy metals $\mathrm{Zn}, \mathrm{Cu}$ and $\mathrm{Pb}$ for SS and MSWC, in comparison with the control was higher for the DTPA-extractable than for the 'total' form. To compare the relative availability of different soil metals, DTPA/Total ratio is used to give available metals as a percentage of total soil metal. Relative availabilities, calculated in this way are given in Table 3. Relative metal availability, expressed as DTPA/Total ratios, was greater for $\mathrm{Zn}, \mathrm{Cu}$ and $\mathrm{Pb}$ than the other metals in the greenhouse soil. Metals in control (manure) treatment were the least relative availability. Relative availability of Zn was the highest in SS treatment. Copper was more available in MSW treated plots. Relative availability of $\mathrm{Pb}$ was almost similar in SS and MSWC treatments. It should be noted that available metal may be quite large when the total metal present in the soil is great.

In the untreated soil (Table 1), DTPA solution extracted about $7.5 \%$ of total $\mathrm{Zn}, 10.8 \%$ of total $\mathrm{Cu}, 2.9 \%$ of total $\mathrm{Ni}$, $8.9 \%$ of total $\mathrm{Pb}$ and $0.7 \%$ of total $\mathrm{Cd}$. DTPA-extractable Ni and $\mathrm{Cd}$ did not change significantly among the treatments, while DTPA-extractable $\mathrm{Zn}, \mathrm{Cu}$ and $\mathrm{Pb}$ gradually increased in direct proportion to the amounts of SS and MSWC added to soil. These results are in concordance with the data [21], and support the hypothesis that metals added with sewage sludge may be more mobile in soil than native metals [22].

Simple correlation coefficients ( $r$ ) between 'total' metals and DTPA-extractable metal content are reported in Table 4. With the exception of $\mathrm{Cd}$ (due to the unavailability of the relevant data) statistically significant and positive correlations were observed between 'total' and DTPA-extractable concentrations in the soil for all metals. Correlation coefficients between DTPA-extractable metals and 'total' metals were increased by the repeated applications of SS and MSWC for all metals except $\mathrm{Cu}$.

TABLE IV: SIMPLE LINEAR COEFFICIENTS BETWEEN DTPA-EXTRACTABLE METALS AND 'TOTAL' METALS IN THE SOIL

\begin{tabular}{|c|c|c|c|c|c|}
\hline \multirow{3}{*}{$\begin{array}{l}\text { Total } \\
\text { metals }\end{array}$} & \multicolumn{5}{|c|}{ DTPA-extractable metals } \\
\hline & $\mathrm{Zn}$ & $\mathrm{Cu}$ & $\mathrm{Ni}$ & $\mathrm{Pb}$ & $\mathrm{Cd}$ \\
\hline & $0.966 * *$ & $0.814 * *$ & $0.528 * *$ & $0.757 * *$ & NS \\
\hline
\end{tabular}

*: Significant with $\mathrm{P} \leq 0.05$; **: Significant with $\mathrm{P} \leq 0.01$; NS: not significant.

\section{C.Metal Speciation}

Figure 1, 2 and 3 report the fractionation of heavy metals in greenhouse control soil and soil amended with SS and MSWC, respectively. For all metals, agreement between fractional total metal values and aqua regia extractable metal values are generally acceptable $(100 \pm 5 \%)$ rate. Concentrations of $\mathrm{Zn}, \mathrm{Cu}, \mathrm{Ni}, \mathrm{Pb}$ and $\mathrm{Cd}$ in control soil fractions were given in Figure 1. The distribution of metals in greenhouse control soil samples generally followed the order below for the metals studied:

$\mathrm{Zn}: \mathrm{F} 1<\mathrm{F} 3<\mathrm{F} 2<\mathrm{F} 4<\mathrm{F} 5$

$\mathrm{Cu}: \mathrm{F} 1 \leq \mathrm{F} 3<\mathrm{F} 2<\mathrm{F} 4<\mathrm{F} 5$

Ni: F $1<\mathrm{F} 3<\mathrm{F} 2<\mathrm{F} 4<\mathrm{F} 5$

$\mathrm{Pb}: \mathrm{F} 1 \leq \mathrm{F} 3<\mathrm{F} 2<\mathrm{F} 4<\mathrm{F} 5$

Cd: $\mathrm{F} 1<\mathrm{F} 2<\mathrm{F} 3<\mathrm{F} 4<\mathrm{F} 5$

The study of the distribution of metals in control soil showed that the greatest percentage of all metals was present in the residual fraction (F5). F1, F2 and F3 fractions of Cd in control soil were higher than other metals. Amendment incorporation into the greenhouse soil significantly increased the sum of metal concentrations in the mobile fractions (Figure 2, 3). Chemical forms of metals in SS and MSWC may vary, depending on the solid-phase components present and their ability to release the metal, $\mathrm{pH}$, temperature, number and accessibility of adsorption sites, metal affinity for solid components and operational parameters of the extraction process [23].

The distribution trends of $\mathrm{Zn}, \mathrm{Cu}$ and Ni metals in SS and MSWC amendments were generally followed the $\mathrm{F} 1<\mathrm{F} 3<\mathrm{F} 2<\mathrm{F} 4<\mathrm{F} 5$ order. In MSWC amendments speciations of $\mathrm{Cd}$ metal was followed $\mathrm{F} 3 \leq \mathrm{F} 4<\mathrm{F} 1<\mathrm{F} 2<\mathrm{F} 5$ the soil fractions. This property possibly gives $\mathrm{Cd}$ metal a high mobility. Despite the low total $\mathrm{Cd}$ concentrations in sludge and MSWC studied, the high solubility of $\mathrm{Cd}$ in the exchangeable phase indicates that this element could cause environmental damage and thus, the rate of sludge and MSWC applications should be taken into account [24].

The most mobile metal fraction in control soil was detected in $\mathrm{Cd}$ and the most immobile metal fractions were detected in Zn. Zinc largely associated with residual phase. However, an important portion of $\mathrm{Cd}$ was in labile form. SS and MSWC amendments increased F1, F2 and F3 fractions for all metals specially $\mathrm{Cu}, \mathrm{Pb}$ and $\mathrm{Cd}$ studied. These results indicate the higher percentages of metals in soluble, 
exchangeable and bound to Fe-Mn oxide fractions. The residual phase represents metals largely embedded in the crystal lattice of the soil fraction and should not be available for remobilization except under very harsh conditions [10].

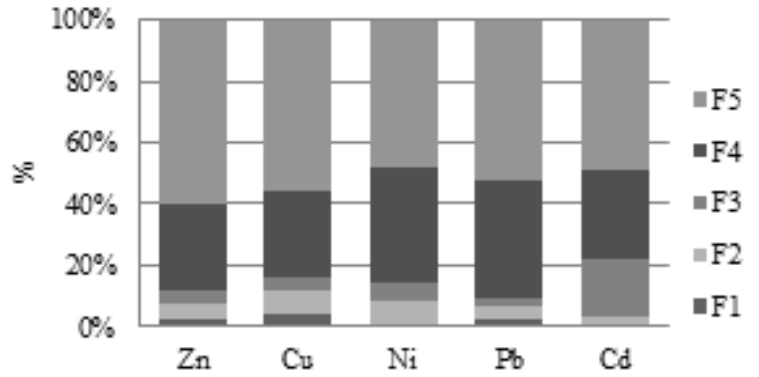

Fig. 1: Distrubution of $\mathrm{Zn}, \mathrm{Cu}, \mathrm{Ni}, \mathrm{Pb}$ and $\mathrm{Cd}$ in the different fractions of control soil.

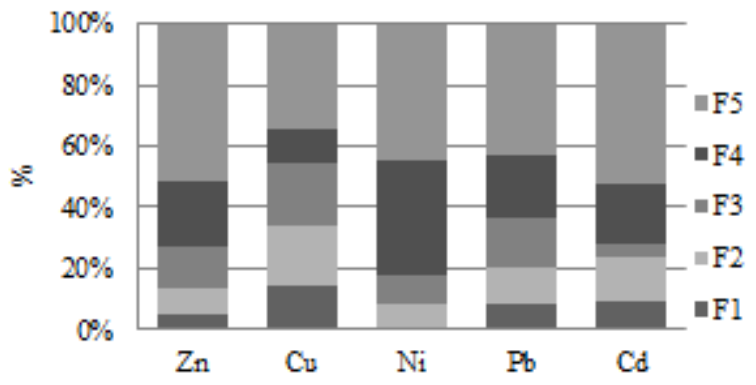

Fig. 2: Distrubution of $\mathrm{Zn}, \mathrm{Cu}, \mathrm{Ni}, \mathrm{Pb}$ and $\mathrm{Cd}$ in the different fractions of SS amended soil.

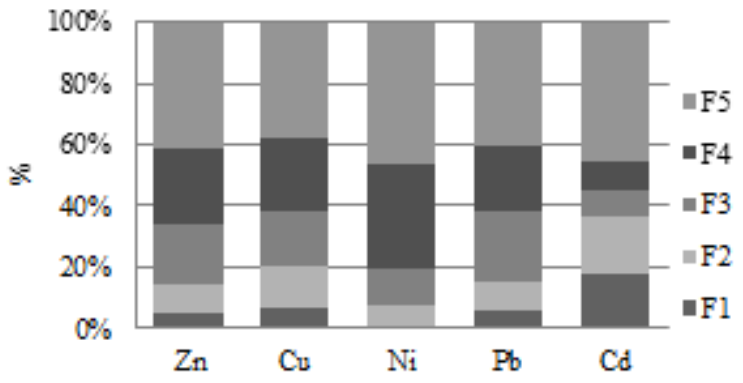

Fig. 3: Distrubution of $\mathrm{Zn}, \mathrm{Cu}, \mathrm{Ni}, \mathrm{Pb}$ and $\mathrm{Cd}$ in the different fractions of MSWC amended soil.

\section{D.Mobility of metals}

Due to some metal forms are strogly bound to soil components than those exracted in F1, F3 and F3, the mobility of metals in soil samples may be evaluated on the basis of absolute and relative content of fractions weakly bound to soil component. Relative index of metal mobility was calculated as a 'mobility factor' (MF) [25] on the basis of the following equation:

$$
\mathrm{MF}: \frac{\left(\mathrm{F}_{1}+\mathrm{F}_{2}+\mathrm{F}_{3}\right)}{\left(\mathrm{F}_{1}+\mathrm{F}_{2}+\mathrm{F}_{3}+\mathrm{F}_{4}+\mathrm{F}_{5}\right)} x 100
$$

This equation is largely describes the potential mobility of metals. The MF values in control soil were considerably higher for $\mathrm{Cd}$. SS and MSWC applications increased MF values for all metals. MSWC applications to greenhouse soil caused higher MF values of for all metals with the exception of $\mathrm{Cu}$ than SS applications. Cupper was detected as the most mobile metal in SS amendments. The high MF values have been interpreted as symptoms of relatively high lability and biological availability of heavy metals in soils [25]. Using the upper baseline criterion, $95 \%$ of greenhouse soils present a relatively higher content of extractable heavy metals given their $\mathrm{Cd}$ and $\mathrm{Cu}$ concentration [26]. The results of the present study suggest that the mobility of the metals in control, SS and MSWC amendments declines in the following order, respectively: $\mathrm{Cd}>\mathrm{Cu}>\mathrm{Ni}>\mathrm{Zn}>\mathrm{Pb}$, $\mathrm{Cu}>\mathrm{Pb}>\mathrm{Cd}>\mathrm{Zn}>\mathrm{Ni}$ and $\mathrm{Cd}>\mathrm{Pb}>\mathrm{Cu}>\mathrm{Zn}>\mathrm{Ni}$ (Figure 4).

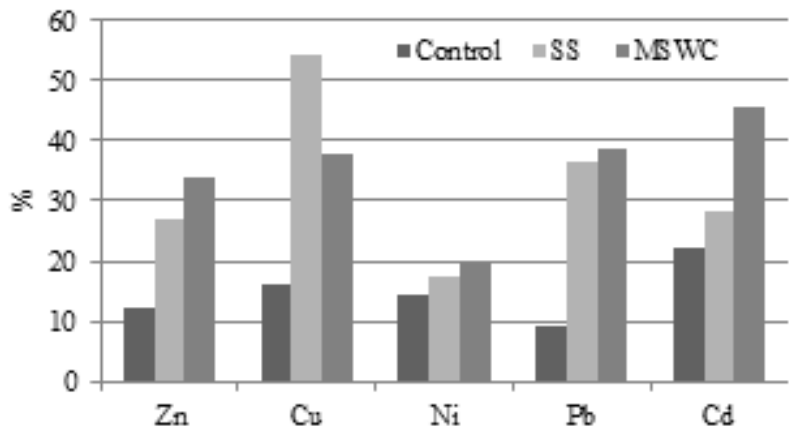

Fig. 4: Average metal mobilities of greenhouse soils amended with SS and MSWC.

\section{E. Contamination evaluation of heavy metals}

Single-factor and composite pollution index of soil: Singlefactor pollution index $(\mathrm{Pi})$ has been used to evaluate the degree of multi-element contamination. This is considered a better method of evaluation because heavy metals contamination in the surface environment is associated with a coctail of contaminants rather than one element. Single indices are indicators used to calculate only one metal contamination:

$$
P_{i}: C_{i} / S_{i}
$$

where $P i$ is the single factor pollution index or contamination factor of heavy metal; $C i$ is the measured contamination value of heavy metal, $S i$ is the environmentally background contamination value of heavy metal.

Composite Pollution Index (PN) was applied to assess the quality of soil environment widely [12] and was defined as:

$$
P I_{\text {Nemerow }}=\sqrt{\frac{\left(\frac{1}{m} \sum_{i=1}^{m} P_{i}\right)^{2}+P_{\text {imax }}{ }^{2}}{2}}
$$

where $P i$ is the single factor pollution index or contamination factor of heavy metal, $P_{\text {imax }}$ is the maximum values of the single pollution indices of all heavy metals, $m$ is the count of the heavy metals species.

Single-factor and composite pollution coefficient of heavy metals are presented in Figure 5. It is clear that all contamination coefficients of metals in grennhouse soil were not exceeded critical value 1. Composite Pollution Index values of greenhouse soil amended with manure, SS and MSWC were also found below the critical value. Thus, all of soil samples may be considered as less contaminated by amendments and may be acceptable clean. The average Pi of heavy metals in greenhouse soils were ranked in the following order $\mathrm{Zn}<\mathrm{Ni}<\mathrm{Cu}<\mathrm{Pb}>\mathrm{Cd}$. 


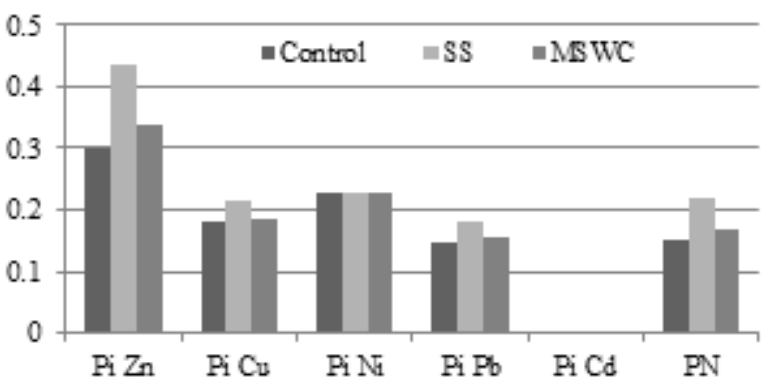

Fig. 5: Single-factor and composite pollution coefficient of heavy metals

Potential ecological risk factor indexes: An ecological risk factor (Er) to quantitatively express the potential ecological risk of a given contaminant [13] is:

$$
R I=\sum_{i=1}^{n} E_{y}^{i} ; \quad E_{y}^{i}=T_{y}^{i} \times C_{f}^{i}
$$

where $T_{r}$ is the toxic-response factor for a given substance, and $C_{f}$ is the contamination factor, $n$ is the count of the heavy metal species. Although the risk factor was originally used as a diagnostic tool for the purpose of controlling water pollution, it was successfully used for assessing the quality of sediments and soils in environment by heavy metals.

The potential ecological risk assessment results of heavy metals in greenhouse soils are summarized in Figure 6. The average monomial risk factors, $\mathrm{Er}$ of heavy metals in greenhouse soils were ranked in the following order $\mathrm{Cd}<\mathrm{Zn}<\mathrm{Pb}<\mathrm{Cu}<\mathrm{Ni}$. In order to quantify the overall potential ecological risk of observed metals in the greenhouse soils, general ecological risk factor (RI) value was calculated as the sum of all the risk factors. The average monomial risk for heavy metals were found below the 40 that indicate all metals posed low risk to surrounding ecosystem in short or mediumterm.

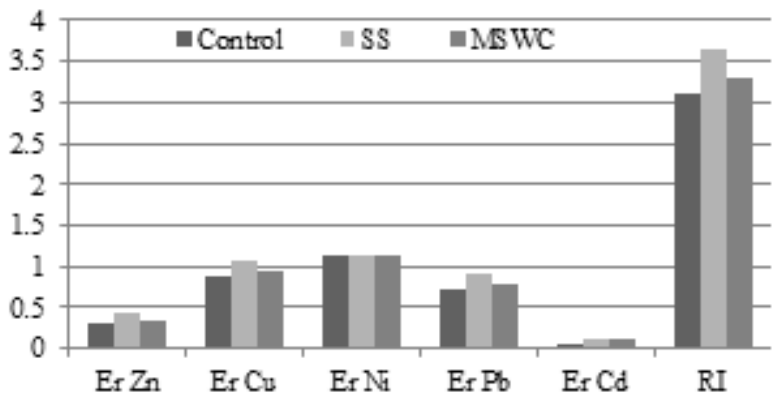

Fig. 6: Ecological risk index (Er) and Potential ecological indexes (RI) of metals in greenhouse soils by amendments.

Risk Assessement Code (RAC): RAC classifies the risk levels based on the chemical speciation of heavy metals and reflects ecological risks. RAC determines the availability of heavy metals in sediments by applying a scale to the percentage of heavy metals in exchangeable and carbonate fraction [11]. In this study RAC parameter is modified to greenhouse soils. According to RAC guideline, classification of RAC is: $<1 \%$ : no risk, 1-10 \%: low risk; 11-30\%: medium risk; 31-50\%: high risk; >50 very high risk (Figure 7).

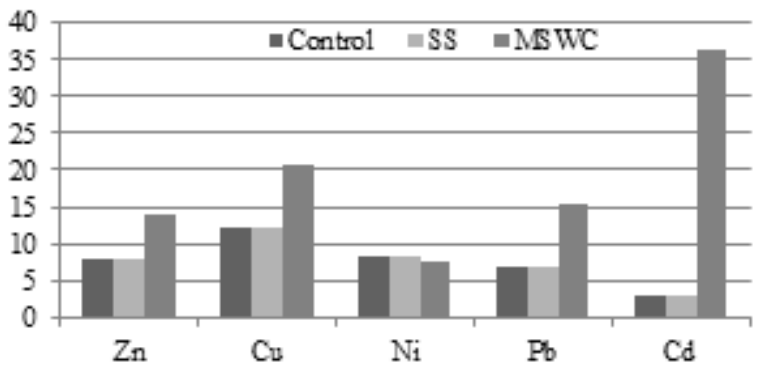

Fig. 7: RAC values of soil heavy metals

According to RAC values of soils, control treatment (cattle manure) and SS amendments have low risk to ecosystem for all metals with the exception of $\mathrm{Cu}$. However, MSWC amendments increased RAC values and $\mathrm{Cd}$ metal was detected in high risk level in MSWC amendments. It was reported that the heavy metals accumulated to greater levels in the greenhouse topsoils with increasing cultivation periods [27]. These results show that MSWC has a medium or high size risk to ecosystem due to their higher toxicity and percentage in the exchangeable and carbonate fraction which are considered to be easily dissolved into water by acidity and possess an adverse impact on soil biota. The overall pollution degrees of heavy metals are in order of $\mathrm{Cd}>\mathrm{Cu}>\mathrm{Pb}>\mathrm{Zn}>\mathrm{Ni}$.

\section{CONCLUSION}

SS and MSWC led to a far greater introduction of the heavy metals examined and brought about a significant increase in their 'total' form in the soil when compared with the control. However, the concentration of heavy metals in greenhouse soils amended with SS and MSWC were generally below the limits referenced by the $86 / 278 /$ EEC directive to agricultural soils with $\mathrm{pH}>7$.

The results of the present study indicated that soil application of SS and MSWC increased total and DTPAextractable levels of $\mathrm{Zn}, \mathrm{Cu}$ and $\mathrm{Pb}$ in the soil compared to the manure. Relative metal availability, expressed as DTPA/total ratios, was greater for $\mathrm{Zn}, \mathrm{Cu}$ and $\mathrm{Pb}$ in $\mathrm{SS}$ than in MSWC treatments. Compared to manure application, SS and MSWC treated soil often show significantly increased heavy metal contents, especially $\mathrm{Zn}, \mathrm{Cu}, \mathrm{Pb}, \mathrm{Ni}$ and $\mathrm{Cd}$. Repeated applications of SS and MSWC in two years were significantly increased bioavailable metals in the greenhouse soil compared to the control.

SS and MSWC amendments increased soluble, exchangeable and carbonate-bound fractions for all metals, especially $\mathrm{Cu}, \mathrm{Pb}$ and $\mathrm{Cd}$ studied. The most mobile metal fraction in control soil was detected in $\mathrm{Cd}$ and the most immobile metal fractions were detected in $\mathrm{Zn}$. MSWC applications to greenhouse soil caused higher mobility values of for $\mathrm{Zn}, \mathrm{Ni}, \mathrm{Pb}$ and $\mathrm{Cd}$ than SS applications.

Single-factor and composite Pollution Index values of greenhouse soil amended with manure, SS and MSWC were found below the critical value. Ecological risk factors for heavy metals were found below the critical level that indicate all metals posed low risk to surrounding ecosystem in short or medium-term. However, MSWC amendments increased RAC values and $\mathrm{Cd}$ metal was detected in high risk level. 
In this three-years study, no detrimental effects on soil properties were detected and metals in treatments were not higher than the allowed guideline level. However, taking into consideration the high potential bioavailability of heavy metals, repeated applications of SS and MSWC would carry a risk of progressive build-up of available trace elements in the soil in the course of time. For environmentally safe disposal of sewage sludge, immobilisation strategies for heavy metals in organic materials have to be investigated in the long term studies. Results demonstrate the importance of measuring extractable as well as total concentrations and also metal mobility and fractionation in topsoil when assessing likely effects on metal uptakes, and settings soil quality criteria.

\section{REFERENCES}

[1] Beyca, J., De Chant, L., Conditt, M, Jones, B., 1993. Wet bag composting trial yields promising results. biocycle, 34(4): 72-75.

[2] Roe, N.E., Stoffela, P.J., Bryan, H.H., 1993. Utilization of MSWC and other organic mulches on commercial vegetable crops. Compost Sci. Utilization, 1(3):73-84. http://dx.doi.org/10.1080/1065657X.1993.10757892

[3] Alloway, B.J., Jackson, A.P., 1991. The behaviour of heavy metals in sewage sludge-amended soil. Sci. Total Environ., 100, 151-176. http://dx.doi.org/10.1016/0048-9697(91)90377-Q

[4] Mulchi, C.L., Adamu, C.A., Bell, P.F., Chaney, R.L., 1991. Residual heavy metal concentrations in sludge-amended coastal plain soils. I. Comparison of extractans. Commun. Soil Sci. Plant Anal., 22(9/10):919941. http://dx.doi.org/10.1080/00103629109368464

[5] Planquart, P., Bonın, G., Prone, A., Massianı, C., 1999. Distribution movement and plant availability of trace metals in soils amended with sewage sludge composts: application to low loadings. The Science of the Total Environment, 241,161-179. http://dx.doi.org/10.1016/S0048-9697(99)00338-1

[6] C.E.C., 1986. Council of the European Communities. Directive of 12 June 1986 on the protection of the environment, and in particular of the soil, when sewage sludge is used in agriculture (86/278/CEE). Official Journal of the European Communities, L181, 6-12.

[7] ISO 11446, 1995. Soil quality-extraction of trace elements soluble in aqua regia. 03-01.

[8] Lindsay, W.L., Norwell, W.A., 1978. Development of a DTPA soil test for zinc, iron, manganese, and copper. Soil sci. Soc. Am. J., 42, 421-428. http://dx.doi.org/10.2136/sssaj1978.03615995004200030009x

[9] Tessier, A., Campbell, P.G.C., Bison, M., 1979. Sequental extraction procedure for the speciation of particulate trace metals. Anal. Chem. 51, 844-851. http://dx.doi.org/10.1021/ac50043a017

[10] Yusuf, K.A., 2007. Sequental extraction of lead, copper, cadmim and zinc in soils near ojota waste site. Journal of Agronomy 6(2):331-337. http://dx.doi.org/10.3923/ja.2007.331.337

[11] Singh, K.P., Mohan, D., Singh V.K., Malik, A., 2005. Studies on distribution and fractionation of heavy metals in Gomti river sediments-A tributary of the Ganges, India [J]. Journal of Hydrology, 312, 14-27. http://dx.doi.org/10.1016/j.jhydrol.2005.01.021

[12] Cheng, J.L., Shi, Z., Zhu, Y.W., 2007. Assesment and mapping of environmental quality in agricultural soils of Zhejiang province, China. Journal of Environmental Sciences, 19:50-54. http://dx.doi.org/10.1016/S1001-0742(07)60008-4

[13] Hakanson, L., 1980. An ecological risk index for aquatic pollution control: A sedimentological approach. Water Research, 14: 975-1001. http://dx.doi.org/10.1016/0043-1354(80)90143-8

[14] Mcgrath, S.P., 1984. Metal concentrations in sludges and soils from a longterm field trial. J. Agric. Sci. 103, 23-35. http://dx.doi.org/10.1017/S002185960004329X

[15] Chang, A.C., Granato, T.C., Page, A.L., 1992. A methodology for establishing phytotoxicity criteria for $\mathrm{Cr}, \mathrm{Cu}, \mathrm{Ni}$ and $\mathrm{Zn}$ in agricultural land application of municipal sewage sludges. J. Environ. Qual. 13, 87-91. http://dx.doi.org/10.2134/jeq1984.00472425001300010016x
[16] Soumare, M., Track, F.M.G., Verlas, M.G., 2003. Effects of a municipal solid waste compost and mineral fertilization on plant growth in two tropical agricultural soils of Mali. Bioresource Technology, 86, 15-20. http://dx.doi.org/10.1016/S0960-8524(02)00133-5

[17] Bevaequa, R.F., Mellano, V.J., 1993. Sewage sludge compost's cumulative effects on crop growth and soil properties. Compost Sci. Utilization, 1(3):34-37. http://dx.doi.org/10.1080/1065657X.1993.10757886

[18] Pinamonti, F., Stringari, G., Gasperi, F., Zorzi, G., 1997. The use of compost: it's effects on heavy metal levels in soil and plants. Resources, Conservation and Recycling, 21, 129-143. http://dx.doi.org/10.1016/S0921-3449(97)00032-3

[19] Ramachandran, V., D'Souza, T.J., 2002. Plant uptake of cadmium, zinc and manganese from four contrasting soil amended with Cd-enriched sewage sludge. Journal of Environ. Sci. And Health, Part AToxic/Hazardous Substances \& Env. Engineering, 37(7): 1337-1346.

[20] Wallace, A., Wallace, G.A., 1994. A possible flaw in EPA's 1993 new sludge rule due to heavy metal interactions. Commun. Soil Sci. Plant Anal. $25,129-135$. http://dx.doi.org/10.1080/00103629409369019

[21] Sanders, S.R., Mcgrath, S.P., Adams, T. MCM., 1987. Zinc, copper and nickel concentration in soil extracts and crops grown on four soils treated with metal-loaded sewage-sludge. Environ. Pollut. 44, 193-210. http://dx.doi.org/10.1016/0269-7491(87)90003-0

[22] Chander, K., Brookes, P.C., 1993. Residual effects of zinc, copper and nickel in sewage sludge on microbial biomass in a sandy loam. Soil Biol. Biochem. 25, 1231-1239. http://dx.doi.org/10.1016/0038-0717(93)90219-2

[23] Alvarez, A.E., Callejon, M., Jimenez, J.C., Ternero, M., 2002. Heavy mtal extractable forms in sludge from wastewater treatment plants. Chemosphere, 47, 765-775. http://dx.doi.org/10.1016/S0045-6535(02)00021-8

[24] Garcia-Delgado, M., Rodriguez-Cruz, M.S., Lorenzo, L.F., Arienzo, M., Sanchez-Martin, M.J., 2007. Seasonal and time variability of heavy metal content and of its chemical forms in sewage sludges from different wastewater treatment plants. Science of the Total Environment, 328, 8292. http://dx.doi.org/10.1016/j.scitotenv.2007.04.009

[25] Soon, Y.K., Abboud, S., 1990. Trace elements in agricultural soils of North-western Alberta. Can.J. Soil Sci. 70, 277-288. http://dx.doi.org/10.4141/cjss90-029

[26] Ramos-Miras, J.J., Roca-Perez, L., Guzman-Palomino, M., Boluda, R., Gil, C., 2011. Background levels and baseline values of available heavy metals in mediterranean greenhouse soils (Spain). Journal of Geochemical Exploration, 110, 186-192. http://dx.doi.org/10.1016/j.gexplo.2011.05.009

[27] Huang, X., Li, T., Yu, H., Zheng, Z., Zhang, X., 2011. Potential risks of heavy metal pollution in greenhouse soils cultivated for different periods. 5th International Conference on Bioinformatics and Biomedical Engineering, (iCBBE), 10-12 May 2011 (http://ieeexplore.iee.org/xpl/articleDetails.jsp?arnumber=5781595). 